\title{
A negative iodine balance is found in healthy neonates compared with neonates with thyroid agenesis
}

\author{
B Bakker ${ }^{1}$, T Vulsma $^{1}$, J de Randamie ${ }^{1}$, A M Achterhuis ${ }^{1}$, \\ B Wiedijk', H Oosting ${ }^{2}$, C Glas ${ }^{3}$ and J J M de Vijlder ${ }^{1}$ \\ ${ }^{1}$ Academic Medical Center, University of Amsterdam, Emma Children's Hospital AMC, Division of Pediatric Endocrinology, Amsterdam, The Netherlands \\ ${ }^{2}$ Department of Clinical Epidemiology and Biostatistics, Academic Medical Center, Amsterdam, The Netherlands \\ ${ }^{3}$ Friesland Nutrition - FDF, Leeuwarden, The Netherlands \\ (Requests for offprints should be addressed to B Bakker, Academic Medical Center, University of Amsterdam, Emma Children's Hospital AMC, Division of \\ Pediatric Endocrinology, P.O. Box 22700, 1100 DE Amsterdam, The Netherlands)
}

\begin{abstract}
We studied the effects of the presence or absence of the thyroid gland on the iodine metabolism and excretion in term Dutch newborns by performing a retrospective study of the urinary iodine excretion in 193 term newborns with abnormal congenital hypothyroidism screening results. Thirty-six euthyroid newborns with decreased thyroxine-binding globulin levels were compared with 157 hypothyroid patients, 54 due to thyroid agenesis and 103 due to thyroid dysgenesis. A significant difference in the urinary iodine excretion was observed between the agenesis group (mean: $28 \mu \mathrm{g} / 24 \mathrm{~h}$ ) and the euthyroid newborns (mean: $46 \mu \mathrm{g} / 24 \mathrm{~h}, P=0 \cdot 001$ ).
\end{abstract}

In conclusion, healthy, euthyroid, term newborns excreted more iodine in their urine than newborns with thyroid agenesis. These results strongly indicated the existence of a temporarily negative iodine balance: the excretion of iodine prevailed over the intake and the newborn's thyroidal iodine, stored during pregnancy, could be used for thyroxine synthesis in the postnatal period. Since healthy term neonates were able to maintain adequate plasma free thyroxine concentrations under normal TSH stimulation, the prenatally acquired iodine stores could be considered sufficiently high to compensate for the transient postnatal losses.

Journal of Endocrinology (1999) 161, 115-120

\section{Introduction}

An insufficient supply of the scarce but essential micronutrient iodine, an integral part of thyroid hormone, results in impaired thyroxine $\left(\mathrm{T}_{4}\right)$ production. Iodine deficiency is a current health risk for roughly one-fifth of the earth's population, and is especially a threatening condition for normal brain development during the period from early pregnancy to infancy. Measurement of urinary iodine excretion is considered to be a reliable indicator of iodine status (Recommended Daily Allowances 1989). In the steady-state condition in adults there is a close relationship between intake and excretion of iodine.

There are marked regional differences in urinary iodine excretion and, hence, in dietary iodine intake throughout Europe (Delange 1996b). In The Netherlands, potassium iodide is added to bread and table salt. Groups consuming little bread or unsalted bread such as female adolescents and elderly people are reported to have borderline urinary iodine excretions (Van Rees-Wortelboer et al. 1987) and develop goitre related to iodine deficiency (Brug et al. 1992). Pregnant women on a salt-restricted diet (and consequently their newborns) are also at risk. Within a population, newborns are one of the groups vulnerable to iodine deficiency; a shortage of $\mathrm{T}_{4}$ will impair normal central nervous system development. The exact iodine intake in newborns is almost impossible to measure. The iodine supply at large is considered to be sufficient when the vulnerable groups in a population also attain a sufficient dietary intake. In The Netherlands little research has been done regarding urinary iodine excretion in healthy newborns and those with congenital hypothyroidism (Gons et al. 1985, Delange \& Bürgi 1989).

Our main aim was to investigate whether the neonatal supply of iodine in The Netherlands is sufficient or marginal as in certain groups of Dutch adults. Investigation of iodine excretion in newborns with different aetiologic categories of congenital hypothyroidism $(\mathrm{CH})$ may provide an insight into the supply and metabolism of iodine in this age group. The 24-h urinary iodine excretion data of term Dutch newborns referred to paediatricians because of aberrant $\mathrm{CH}$ screening results were analysed retrospectively. We focused on differences in urinary iodine excretion between newborns with thyroid agenesis where there is no buffer compartment for iodine, or with thyroid dysgenesis where there is restricted potential for 
accumulating iodine and newborns with decreased thyroxine-binding globulin (TBG) concentrations where there is completely normal thyroid hormone status. The data allowed us to make some suggestions about the iodine pool in the thyroid gland.

\section{Patients and Methods}

\section{Patients}

All the neonates that were studied were born between 1983 and 1996 and were referred to their local paediatrician because of aberrant $\mathrm{CH}$ screening results. As part of the aetiologic classification procedure, Dutch paediatricians are advised to collect 24-h urine specimens for the determination of total iodine excretion (Gons et al. 1983). Urine samples were collected at a mean age of 23 days and the collections were nationwide. We excluded those patients with a history of pre- or postnatal exposure to excessive amounts of iodine, those with thyroid dyshormonogenesis, preterm infants (gestational age $<37$ weeks), and those with incomplete data (less than a 24-h collection period, where data on gestational age were missing and where there there was uncertainty about the aetiology). In this way we obtained a total of 193 patients (111 girls and 82 boys): 36 with decreased TBG concentrations, 54 with thyroid agenesis and 103 with thyroid dysgenesis. Twenty-four-hour collections were mostly done before the initiation of $\mathrm{T}_{4}$ therapy. In more recent years it has become clear that $\mathrm{T}_{4}$ therapy should never be delayed because of the diagnostic process. This means that in the 1990s $\mathrm{T}_{4}$ therapy might have been started in some patients whilst the 24-h urine collection was being made; see also the Discussion.

\section{Methods}

In The Netherlands, the screening method for $\mathrm{CH}$ is primarily performed as $\mathrm{T}_{4}$ screening, with additional thyrotrophin (TSH) determinations in the $20 \%$ of samples with the lowest $\mathrm{T}_{4}$ concentrations. The advantage of the $\mathrm{T}_{4}$ screening programme, to which in 1995 a TBG determination was added, is the detection of secondary and tertiary hypothyroidism. Depending on the levels of total $\mathrm{T}_{4}$, TSH and the $\mathrm{T}_{4} / \mathrm{TBG}$ ratio a child is either referred to a paediatrician directly or a second heel puncture is done.

We received frozen 50-100 $\mathrm{ml}$ specimens of 24-h urine collections. After destruction with chloric acid, the iodine concentration was measured in urine, milk and formula by the cerium-arsenite method (de Vijlder et al. 1978), using a Cobas Fara spectrophotometer (Hoffmann-la Roche Ltd, Basel, Switzerland). The detection level of the assay is $5 \mu \mathrm{g} / 1$, intra- and interassay coefficients of variation are at most $3 \cdot 7$ and $3 \cdot 3 \%$ respectively.

\section{Aetiologic classification}

The euthyroid group consisted of healthy children with normal plasma free thyroxine $\left(\mathrm{FT}_{4}\right)$ and $\mathrm{TSH}$ concentrations and a decreased TBG concentration (TBG $<380 \mathrm{nmol} / 1$ or $20 \mathrm{mg} / \mathrm{l}$ ). Children with agenesis of the thyroid gland had, at the time of detection, very low but detectable $\mathrm{FT}_{4}$ levels (reflecting the exponentially decreasing amounts of $\mathrm{T}_{4}$ from maternal origin (Vulsma et al. 1989)), very high TSH concentrations and undetectable plasma thyroglobulin concentrations. On imaging studies $\left({ }^{123} \mathrm{I}^{-}\right.$, ultrasound) no thyroid tissue could be demonstrated in the neck/head region. Patients with a dysgenetic thyroid gland (characterised by a dystopic remnant at radioiodide imaging) had variable decreased plasma $\mathrm{FT}_{4}$ and variable plasma thyroglobulin concentrations. The methods for aetiologic classification have been described in detail previously (de Vijlder \& Vulsma 1996).

\section{Statistical analysis}

To compare the mean urinary iodine excretions of the three groups, the Kruskal-Wallis test was used. When significant differences were found, the means were compared by the Mann-Whitney test. $P$ Values were corrected by means of the Bonferroni method. The Mann-Whitney test was also used for comparison of urinary iodine excretion with respect to gender. The urine samples were collected over a long period (1983-1995). Cohorts of 1 year were created; one-way analysis of variance (ANOVA) was used for comparison of the values of these cohorts. One-way ANOVA was also used to check for differences between the day of collection and for differences in urinary iodine excretion in the 12 different provinces of The Netherlands. Analysis of covariance (BMDP statistical software, Cork Technology Park, Cork, Republic of Ireland) was applied for comparing the difference in urinary iodine excretion between groups with a correction for the day of collection, the latter being the covariate.

\section{Fluid balance}

In order to make calculations on milk intake (breast milk or formula) and urine production we used the well-known relationship between caloric expenditure and water balance (Finberg et al. 1982). This approach gives the most accurate way of determining insensible water losses in neonates, giving us the ability to perform a control on the 24-h urine sampling. We accepted that the daily nonurinary water loss was $50 \mathrm{ml} / \mathrm{kg}$ per $24 \mathrm{~h}$ for euthyroid neonates (see Table 1), $45 \mathrm{ml} / \mathrm{kg}$ per $24 \mathrm{~h}$ as evaporation losses through skin and lungs and $5 \mathrm{ml} / \mathrm{kg}$ per $24 \mathrm{~h}$ as water loss via defaecation (McCance 1973, Finberg et al. 1982). The daily milk intake for the euthyroid newborns 
Table 1 Daily water volumes in insensible loss, milk intake and urinary output

Euthyroid neonates (TBG deficiency)

\section{Parameter}

Daily non-urinary water

Average daily milk intake

Daily urinary production

Mean stated 24-h urinary volume

Mean calculated 24-h urinary volume $(4 \mathrm{~kg})$
$50 \mathrm{ml} / \mathrm{kg}$ per day $175 \mathrm{ml} / \mathrm{kg}$ per $24 \mathrm{~h}$ * $125 \mathrm{ml} / \mathrm{kg}$ per $24 \mathrm{~h}$ $301 \mathrm{ml} / 24 \mathrm{~h}$

$500 \mathrm{ml} / 24 \mathrm{~h}$
*Lower limit=150 ml/kg per day, upper limit=200 ml/kg per day.

at the age of 4 weeks post partum was assessed to be $150-200 \mathrm{ml} / \mathrm{kg}$ per $24 \mathrm{~h}$. This results in an average water intake of $175 \mathrm{ml} / \mathrm{kg}$ per $24 \mathrm{~h}$ (McCance 1973) at this age. We calculated that the daily urinary production on the basis of a $4 \mathrm{~kg}$ body weight at the age of 3 weeks would be $500 \mathrm{ml} / 24 \mathrm{~h}$ (see Table 1). To check whether the 24-h urine samples were collected correctly, we made calculations on food intake and 24-h urinary excretion at the time of collection, using the above-mentioned relationship between caloric expenditure and water balance.

With a determined mean iodine content in breast milk of $103 \mu \mathrm{g} / 1$ (95\% confidence interval (CI): 83-123) and of $124 \mu \mathrm{g} / 1$ (95\% CI: 119-128) in formula (this study, see Results), we calculated the mean daily iodine intake. With an estimated weight of $4 \mathrm{~kg}$ at the age of 4 weeks, the euthyroid child drinks a total of $4 \times 175 \mathrm{ml}$ (see Table 1) $=700 \mathrm{ml} /$ day. This gives a mean daily iodine intake of $72 \mu \mathrm{g}$ (95\% CI: 58-86) for breast-fed newborns and $86 \mu \mathrm{g}$ (95\% CI: 83-90) for bottle-fed newborns. These amounts are higher than the mean measured excreted amount of $46 \mu \mathrm{g}$ iodine (95\% CI: 37-56) per day (see Table 2). Because most Dutch newborns are breast-fed we will focus on the calculations for breast-fed children. The mean 24-h urinary volume that we calculated was $500 \mathrm{ml}$ and the mean 24-h volume that was stated was $301 \mathrm{ml}$ (see Table 1). This $40 \%$ difference can be explained either by losses during urine collection and/or non-urinary iodine losses. The first possibility is most likely because a 24-h collection of urine in plastic sample bags with an adhesive layer around the genitalia is a well-known troublesome procedure.

It is highly conceivable that this 40\% loss in 24-h urine collection also applies to the thyroid agenesis and dysgenesis groups, meaning that the significant difference in 24-h urinary iodine excretion between the agenesis group and the euthyroid group remains.

\section{Results}

The three groups together, with a total of 193 neonates with known aetiologies, had a mean urinary iodine excretion of $37 \mu \mathrm{g} / 24 \mathrm{~h}$ (Table 2 ). No significant differences in urinary iodine excretion between girls $(n=111)$ and boys $(n=82)$ were observed. The 24-h urine samples, collected from 1983 till 1996, were analysed in cohorts of 1 year and one-way ANOVA did not reveal any significant difference over these years $(P=0 \cdot 75)$. No significant geographical differences are found in The Netherlands.

The euthyroid group had a mean iodine excretion of $46 \mu \mathrm{g} / 24 \mathrm{~h}$ and the thyroid agenesis group $28 \mu \mathrm{g} / 24 \mathrm{~h}$ (Table 2). This difference is statistically significant $(P=0 \cdot 001$ by the Mann-Whitney test), also after correction for the age at collection. The thyroid dysgenesis group had an in-between mean urinary iodine excretion of $38 \mu \mathrm{g} / 24 \mathrm{~h}$. The euthyroid group as compared with the thyroid agenesis group not only had a higher iodine excretion per day (expressed in $\mu \mathrm{g} / 24 \mathrm{~h}$ ) but also in concentration (expressed in $\mu \mathrm{g} / \mathrm{l}$ ). A slight increase in urinary iodine excretion was observed when the collection time was at a later age (data not shown), probably related to the increasing daily volume of milk that the growing infant drinks. The euthyroid group was investigated later than the agenesis group (see Table 2) due to later referral. However, this increase in urinary iodine excretion because of a later collection time does not account for the difference found between the euthyroid and agenesis groups, as calculated by analysis of covariance.

A recent analysis in our laboratory of the food of Dutch neonates revealed a mean iodine concentration of $103 \mu \mathrm{g} / 1$

Table 2 Urinary iodine excretion in relation to the aetiological category in neonates referred because of an abnormal $\mathrm{CH}$ screening result

\begin{tabular}{|c|c|c|c|c|c|c|c|c|c|}
\hline & \multirow{2}{*}{$\begin{array}{l}\text { Number of } \\
\text { neonates } \\
\text { (girls) }\end{array}$} & \multirow{2}{*}{$\begin{array}{l}\text { Mean age at } \\
\text { collection } \\
\text { (days) }\end{array}$} & \multicolumn{2}{|c|}{$\begin{array}{l}\text { Urinary iodine } \\
\text { excretion } \\
\text { in } \mu \mathrm{g} / 24 \mathrm{~h}\end{array}$} & \multicolumn{2}{|c|}{$\begin{array}{l}\text { Urinary iodine } \\
\text { excretion in } \mu \mathrm{g} / \mathrm{l}\end{array}$} & \multirow{2}{*}{$\begin{array}{l}\text { Stated urine } \\
\text { production } \\
(\mathrm{ml} / 24 \mathrm{~h})\end{array}$} & \multirow{2}{*}{$\begin{array}{l}\text { Mean birth } \\
\text { weight }(g)\end{array}$} & \multirow{2}{*}{$\begin{array}{l}\text { Mean } \mathbf{F T}_{4} \\
\text { level }(\mathrm{pmol} / \mathrm{l}\end{array}$} \\
\hline & & & Mean & $95 \% \mathrm{Cl}$ & Mean & $95 \% \mathrm{Cl}$ & & & \\
\hline \multicolumn{10}{|l|}{ Diagnosis } \\
\hline Euthyroid neonates & $36(6)$ & 28 & $46^{*}$ & $37-56$ & 150 & $127-172$ & 301 & 3469 & $18 \cdot 4$ \\
\hline Agenesis & $54(32)$ & 17 & $28^{*}$ & $22-33$ & 121 & 104-139 & 241 & 3592 & $2 \cdot 6$ \\
\hline Dysgenesis & $103(73)$ & 24 & 38 & $34-43$ & 159 & 135-182 & 264 & 3543 & $7 \cdot 5$ \\
\hline \multirow[t]{2}{*}{ All } & $193(111)$ & 23 & 37 & $34-39$ & 148 & 137-159 & & 3465 & $8 \cdot 9$ \\
\hline & & & & $33-40$ & 147 & $132-161$ & & & \\
\hline
\end{tabular}


in breast milk (95\% CI: 83-123 $\mu \mathrm{g} / \mathrm{l})$ and $124 \mu \mathrm{g} / 1$ in formula (95\% CI: $119-128 \mu \mathrm{g} / 1)$.

\section{Discussion}

Thyroid hormone, and hence its unique and indispensable substrate iodine, is very important for cerebral development. Several studies concerning $\mathrm{CH}$ have shown that pre- and postnatal shortage of $\mathrm{T}_{4}$ leads to impaired neurodevelopment (Porterfield \& Hendrich 1993, Kooistra et al. 1994, Derksen-Lubsen \& Verkerk 1996). Even more devastating for neurodevelopment is (severe) iodine deficiency, which impairs both maternal and foetal/ infantile thyroid hormone synthesis (Delange 1996a).

During early pregnancy, the human foetus is completely dependent on the maternal thyroid hormone status, because the foetal thyroid gland secretes hardly any thyroid hormone before 16 weeks of gestation. From that age on foetal thyroid hormone production gradually increases, but the foetus remains completely dependent on the iodine supply by the mother. There are two sources of iodine for the foetus: (1) maternal (inorganic) iodide from alimentary sources, passing through the placenta and (2) maternal iodothyronines, deiodinated in the placenta. The mean amount of iodine stored in the foetal thyroid is dependent on the geographical iodine status; in decreased newborns from Toronto it was measured to be approximately $300 \mu \mathrm{g}$ $(n=13)$, stored in thyroid glands of about $1 \mathrm{~g}$ (Delange \& Ermans 1996). Canadian newborns in this area excrete a mean of $148 \mu \mathrm{g}$ iodine/l urine, nearly the same as that found for Dutch newborns (this study).

After birth the iodine supply changes from the placental to the enteral route. The postnatal sudden rise in plasma thyroid hormone concentrations follows an abrupt increase in TSH within the first few hours after birth. The prenatally stored iodine pool in the thyroid gland allows this sudden increase in thyroid hormone production. In addition to this, the iodine in the ingested milk is important for a continuing production of thyroid hormone. The amount of iodine in milk appears to be variable; we measured a mean of $103 \mu \mathrm{g} / 1$ in breast milk and $124 \mu \mathrm{g} / 1$ in formula. The prenatally stored pool of iodine in the thyroid gland cannot be measured in living neonates.

In order to evaluate the contribution of the prenatally stored thyroidal iodine in maintaining euthyroidism, we compared the urinary iodine excretion per day (and per litre) in newborns having a normal thyroid gland with children without any thyroid tissue. In this thyroid agenesis group the iodine excretion must reflect the postnatal iodine supply.

Urinary iodine excretion can be expressed in several ways: per litre $(\mu \mathrm{g} / \mathrm{l})$, per $24 \mathrm{~h}(\mu \mathrm{g} / 24 \mathrm{~h})$ or per gram creatinine ( $\mu \mathrm{g} / \mathrm{g}$ creatinine), the latter being used when only portions of urine are being studied. The urinary creatinine concentration in our study group varied from
0.5 to $4.0 \mathrm{mmol} / \mathrm{l}$. Given this large variation and also the reports by others that urinary iodine excretion/g creatinine is not a good measure for children (Furnée et al. 1994, Remer \& Manz 1994) we chose to use urinary iodine excretion per $24 \mathrm{~h}$ in our study.

Gons et al. (1985) found in 151 Dutch newborns, with and without $\mathrm{CH}$, a median value of $31 \mu \mathrm{g} / 24 \mathrm{~h}$. The mean urinary iodine excretion of $37 \mu \mathrm{g} / 24 \mathrm{~h}$ in our study is somewhat higher, probably related to group differences. The iodine excretion is much higher than in Denmark (Nøhr et al. 1994), Germany (Peiker et al. 1989) or Spain (Ares et al. 1997).

In the population of newborns studied we found a significantly lower mean iodine excretion in the thyroid agenesis group than in the euthyroid group, both in amount per day ( $\mu \mathrm{g}$ iodine $/ 24 \mathrm{~h}$ ) and per litre urine ( $\mu \mathrm{g}$ iodine/l) (see Table 2). The 40\% calculated loss within the 24-h urine collection (as outlined in the section on Fluid balance) does not affect the significant difference between the agenesis group and the euthyroid group. The fact that some of the more recently studied children might already be on $\mathrm{T}_{4}$ supplementation while collecting 24-h urine samples only adds to the already significant difference in 24-h urinary iodine excretion between the agenesis group and the healthy TBG-deficient group. The agenesis newborns are more likely to have signs and symptoms of hypothyroidism, which incidentally may have led to $\mathrm{T}_{4}$ administration during the 24-h urine collection.

Severely hypothyroid newborns compared with euthyroid children will drink less milk, giving a reduction in urinary iodine excretion. However, if the measured difference was exclusively caused by a reduction in milk intake, one would expect similar reductions in both iodine and water excretions and, as a consequence, equal iodine concentrations in the urine samples of both groups. Because this is not the case (see columns 4 and 6, Table 2) our data are indicative of a transient negative iodine balance (excretion exceeds intake) in the euthyroid newborns.

Another factor possibly contributing to the reduced urinary iodine excretion in the agenesis group might be caused by decreased iodine absorption from the intestinal tract in hypothyroid newborns; however, there are no conclusive data to support this (Vassilipoulou-Sellin \& Sellin 1996).

The renal excretion of iodide shows a half-life of about $7 \mathrm{~h}$ (Bikker et al. 1996). As far as is known this is not significantly affected by thyroid hormone status. Even if the renal excretion was affected by hypothyroidism, this cannot account for a lower iodide excretion, since this would most likely be counteracted via an increase in the plasma iodide concentration.

The age at collection influences urinary iodine excretion. The mean day of collection for the agenesis group was 17 days post partum (95\% CI: 16-19) and 28 days for the euthyroid group (95\% CI: 23-33). By analysis of 
covariance, we calculated that a difference in the time (day) of collection does not account for the differences in urinary iodine excretion between the groups.

Ares et al. (1997) have also described a temporary negative iodine balance during the first week of life in a small group of very premature newborns in Spain. The 24-h urinary iodine excretion in term Spanish newborns was very low (around $5 \mu \mathrm{g} / 24 \mathrm{~h}$ ). Because the mean daily iodine intake in Spain is much lower than in The Netherlands (Delange \& Bürgi 1989, Delange 1996b) it is to be expected that the amount of prenatally accumulated iodine will be lower.

In conclusion, this is the first report to show a negative iodine balance in healthy term newborns living in an iodine-sufficient area (The Netherlands). The extra amount of iodine excreted in the urine of these euthyroid newborns compared with thyroid agenesis patients has to originate from the major storage place of iodine: the thyroid. This negative iodine balance does not jeopardise $\mathrm{T}_{4}$ production and reflects an adequate foetal iodine storage. Apparently the maternal iodine intake in The Netherlands covers the infant's thyroid hormone production during the first weeks of life. Ideally the external iodine supply should never be a rate-limiting factor in the synthesis of thyroid hormone. From our data we cannot exactly calculate the optimal daily iodine intake. In The Netherlands we seem to be on the safe side with the amounts of iodine in both breast milk and formula. In the first days after birth the negative iodine balance can be interpreted as a favourable condition, later on there will be an equilibrium where intake equals output, but this is not the case yet at the age of 3 to 4 weeks post partum.

\section{Acknowledgements}

We thank the many Dutch paediatricians for sending material from their patients and providing clinical data, we also thank Carrie Ris for reading the manuscript and Rein Hilhorst, José Willemsen and Yfke Kimstra for data management. This study was financially supported by Friesland Nutrition - FRIESLAND Dairy Foods, Leeuwarden, The Netherlands. The Ludgardine Bouwman Stichting is gratefully acknowledged for continuous support to J J M d V.

\section{References}

Ares S, Escobar-Morreale HF, Quero J, Duran S, Presas MJ, Herruzo R \& Morreale de Escobar G 1997 Iodine intake in premature versus term infants: urinary iodine excretion and thyroid function. Journal of Clinical Endocrinology and Metabolism 82 1704-1712.

Bikker H, Waelkens JJJ, Bravenboer B \& de Vijlder JJM 1996 Congenital hypothyroidism caused by a premature termination signal in exon 10 of the human thyroid peroxidase gene. Journal of Clinical Endocrinology and Metabolism 81 2076-2079.

Brug J, Löwik MRH, Wedel M \& Odink J 1992 Iodide excretion before and after revision of goitre prophylaxis (Dutch Nutrition Surveillance System). European Journal of Clinical Nutrition 46 671-678.

Delange FM 1996a Endemic cretinism. In The Thyroid, A Fundamental and Clinical Text, edn 7, pp 756-767. Eds LE Braverman \& RD Utiger. Philadelphia: Lippincott-Raven.

Delange FM 19966 The thyroid and iodine. In European Thyroid Symposium, Warsaw. Eds J Nauman, D Glinoer, LE Braverman \& U Hostalek. Stuttgart: Schattauer.

Delange FM \& Bürgi H 1989 Iodine deficiency disorders in Europe. Reviews/Analyses. Bulletin of the World Health Organisation 67 317-325.

Delange FM \& Ermans AM 1996 Intrinsic and extrinsic variables. Iodine deficiency. In The Thyroid, A Fundamental and Clinical Text, edn 7, pp 296-315. Eds LE Braverman \& RD Utiger. Philadelphia: Lippincott-Raven.

Derksen-Lubsen G \& Verkerk PH 1996 Neuropsychologic development in early treated congenital hypothyroidism: analysis of literature data. Pediatric Research 39 561-566.

Finberg L, Kravath RE \& Fleischmann AR 1982 Water metabolism regulation. In Water and Electrolytes, pp 17-22. Eds L Finberg, RE Kravath \& AR Fleischmann. Philadelphia: WB Saunders.

Furnée CA, Haar van der F, West CE \& Hautvast JGAJ 1994 A critical appraisal of goiter assessment and the ratio of urinary iodine to creatinine for evaluating iodine status. American Journal of Clinical Nutrition 59 1415-1418.

Gons MH, Kok JH, Tegelaers WHH \& de Vijlder JJM 1983 Concentration of plasma thyroglobulin and urinary excretion of iodinated material in the diagnosis of thyroid disorders in congenital hypothyroidism. Acta Endocrinologica 104 27-34.

Gons MH, Kok K, Miga GM \& de Vijlder JJM 1985 Urinary iodine excretion in the Netherlands. In Thyroid Disorders Associated with Iodine Deficiency and Excess. Eds R Hall \& J Koebberling. Serono Symposia Publications, vol. 22. New York: Raven Press.

Kooistra L, Laane C, Vulsma T, Schellekens JMH, Van der Meere JJ \& Kalverboer AF 1994 Motor and cognitive development in children with congenital hypothyroidism: A long-term evaluation of the effects of neonatal treatment. Journal of Pediatrics 124 903-909.

McCance RA 1973 The requirements for water and salt. In Therapeutic Aspects of Nutrition, pp 92-99. Eds JHP Jonxis, HKA Visser \& JA Troelstra. Leiden: HE Stenfert Kroese BV.

Nøhr SB, Laurberg P, Børlum KG, Pedersen KM, Johannesen PL, Damm P, Fuglsang E \& Johansen A 1994 Iodine status in neonates in Denmark: regional variations and dependency on maternal iodine supplementation. Acta Paediatrica 83 578-582.

Peiker G, Groppel B, Müller B \& Greinke C 1989 Zur Iodversorgung bei Wöchnerinnen und ihren Neugeborenen. Zentralblatt Gynäkologie 111 364-367.

Porterfield SP \& Hendrich CE 1993 The role of thyroid hormones in prenatal and neonatal neurological development - current perspectives. Endocrine Reviews 14 94-106.

Recommended Daily Allowances 1989 Edn 10. National Research Council. Washington DC: National Academy Press.

Remer T \& Manz F 1994 The inadequacy of the urinary iodinecreatinine ratio for the assessment of iodine status during infancy, childhood and adolescence. Journal of Trace Elements and Electrolytes in Health and Disease 8 217-219.

Van Rees-Wortelboer MM, Schroder-van der Elst JP, Lyklama A \& Van der Heide D 1987 Jodium en krop in Nederland (in Dutch). Nederlands Tijdschrift voor Geneeskunde 131 1821-1824.

Vassilipoulou-Sellin R \& Sellin JH 1996 The gastrointestinal tract and liver in hypothyroidism. In The Thyroid, A Fundamental and Clinical 
Text, edn 7, pp 816-820. Eds LE Braverman \& RD Utiger. Philadelphia: Lippincott-Raven.

de Vijlder JJM, van Voorthuizen WF, van Dijk JE, Rijnberk A \& Tegelaers WHH 1978 Hereditary congenital goiter with thyroglobulin deficiency in a breed of goats. Endocrinology 102 1214-1222.

de Vijlder JJM \& Vulsma T 1996 Hereditary metabolic disorders causing hypothyroidism. In The Thyroid, A Fundamental and Clinical Text, edn 7, pp 749-755. Eds LE Braverman \& RD Utiger. Philadelphia: Lippincott-Raven.
Vulsma T, Gons MH \& de Vijlder JJM 1989 Maternal-fetal transfer of thyroxine in congenital hypothyroidism due to an organification defect or thyroid agenesis. New England Journal of Medicine 321 13-16.

Received 2 June 1998

Revised manuscript received 21 October 1998 Accepted 3 November 1998 